\title{
2段羽口式溶融還元炉による難処理金属スラッジの 資源化技術の開発
}

\author{
内山 武* ·原 義明*2 ·武田 幹治*2 ·上杉 浩之*3 $・$ 中村 崇*4
}

Development of Recovery Technology of Valuable Metal Contained in Industrial Sludge by

Smelting Reduction Furnace with Two-stage Tuyeres

Takeshi Uchiyama, Yoshiaki Hara, Kanji Takeda, Hiroshi Uesugi and Takashi NaKamura

Synopsis : A new technology for recycling stainless pickling sludge has been developed by combination of a smelting reduction process of the sludge and a separation process of fluorine from the pickling.

The stainless pickling sludge, which is generated by the neutralization of the waste pickling liquor, contains valuable metals such as iron, chromium and nickel. The sludge, however, also contains fluorine and the fact has obstructed the recycle of the sludge.

We carried out bench-scale and pilot plant tests of the smelting reduction with coke packed bed in order to develop the recovery technology of valuable metal contained in the sludge. The reduction of the metal hydroxides and the behavior of the fluorine in the furnace were studied through the tests. A newly modified index of heat level was installed. By considering decomposition heat of hydroxide and reaction heat with carbon, reduction indices were uniformly described. Complete recovery of the valuable metals in the sludge was achieved at the pilot plant tests. The fluorine distribution ratio into slag was $21 \%$ and we expect that the fluorine leaching from the slag is $0.32 \mathrm{mg} / l$, which is lower than the environmental standard value of $0.8 \mathrm{mg} / l$. The $\mathrm{pH}$ of the cooling water for the off gas is mainly determined by the balance of the ion contents of fluorine and chlorine as the acid elements and that of calcium, sodium and potassium as the alkali elements.

Key words : industrial sludge; recycle; iron; chromium; nickel; fluorine; smelting reduction; two stage tuyeres; coke packed bed; leaching.

\section{1. 緒言}

金属製造業では年間約 80 万トンのスラッジが発生し， うち $44 \%$ が埋立処分等に供されており ${ }^{1)}$, 十分に有効利用 されているとは言えない。スラッジはその発生プロセスの 違いにより, 主に圧延水処理スラッジ, 酸洗スラッジおよ びめっき系スラッジに大別されるが，製造している鋼種に より成分は様々である。スラッジには鉄，亜鉛，クロムお よびニッケルなどの有価金属が含まれている一方, これら の分離が難しいことおよびフッ素あるいは油分を含むもの があることなど，再資源化を困難にする要因がある。

ステンレス酸洗プロセスでは，フッ硝酸でステンレス鋼 板の表面を洗浄するため, その酸洗廃液には溶解した鉄, クロムおよびニッケルの他, 多量のフッ素が含まれる。ス テンレス酸洗スラッジはこの廃液を消石灰により中和処理 することにより発生するもので, 主成分は金属水酸化物と フッ化カルシウムである。スラッジ中のフッ素濃度は約 20\%であり，たとえば既設の転炉にリサイクルする場合に は, 耐火物の溶損, 転炉スラグのフッ素による污染, 排ガ ス煙道のフッ酸による腐食などの問題がある他, スラッジ
が微粉であることおよびクロム水酸化物が難還元性である ために回収率が低いという問題があり，再資源化は困難で あった。

そこで本研究ではステンレスの酸洗スラッジの資源化を 検討した。酸洗廃液を中和する工程で, ハイブリッド粗分 離法 ${ }^{2} に よ り$ 金属とフッ素を分離し, 脱フッ素されたス ラッジを2段羽口式コークス充填層型溶融還元炉 ${ }^{3)}$ (以下, 2段羽口式溶融還元炉と称する）で処理し，鉄，ク口ムお よびニッケルをメタルとして回収することを考えた。ス ラッジを2段羽口式溶融還元炉で還元するときの課題を以 下に述べる。

第一の問題点はスラッジが金属水酸化物である点にあ る。 $\mathrm{Fe}_{2} \mathrm{O}_{3}$ および $\mathrm{Fe}(\mathrm{OH})_{3}$ の Cによる還元熱はそれぞれ $245^{4)}, 492 \mathrm{~kJ} / \mathrm{mol}-\mathrm{Fe}^{5)} ゙$ あり，還元熱が大きい。2段羽口式 溶融還元炉はクロムを含む金属酸化物系ダスト処理炉とし て実用化されており, 酸化物処理の操業設計技術は確立さ れているが, 還元熱の大きい水酸化物の還元挙動を明らか にし，スラッジを処理する際の操業設計技術を確立する必 要がある。

第二の課題はスラグからのフッ素溶出およびフッ酸によ

平成 14 年 8 月 26 日受付 平成 14 年 12 月 10 日受理 (Received on Aug. 26, 2002; Accepted on Dec. 10, 2002)

* JFEエンジニアリング (株) エンジニアリング研究所 (Engineering Research Center, JFE Engineering Corp., 1-1 Minamiwatarida-cho Kawasaki-ku Kawasaki $210-0855)$

* 2 JFE スチール（株）スチール研究所 (Steel Research Lab., JFE Steel Corp.)

* 3 三洋アクアテクノ (株) (SANYO Aqua Technology Co., Ltd.)

*4 東北大学多元物質科学研究所 (Institute of Multidisciplinary Research for Advanced Materials, Tohoku University) 
る排ガス系配管の腐食である。ハイブリッド粗分離法を用 いれば，最終工程の洗浄を十分に行うことにより，理論的 にはフッ素をほとんど完全に除去することができるが，実 用上はスラッジ中フッ素濃度を 2 4\% (dry base)とするの が現実的である ${ }^{2)}$ 。従って，2段羽口式溶融還元炉スラグ にフッ素が混入し， スラグからのフッ素溶出が土壌利用の 基準值を超えると, スラグの路盤材としての有効活用がで きなくなり，新たな産業廃棄物を発生させることになる。 また，フッ素が排ガス中へ移行すると集塵水が酸性となり， 配管腐食などの問題を発生させることになる。従って， 2 段羽口式溶融還元炉内でのフッ素の挙動を調查し，スラグ および排ガスへのフッ素分配率を把握することが重要であ る。

本研究ではスラッジ処理量 $10 \mathrm{t} / \mathrm{d}$ 規模の 2 段羽口式溶融 還元炉パイロットプラントを用いて，フッ素を含有するス ラッジを処理する実験を実施し，上記の課題を解決するこ とを目的とした。

\section{2段羽口式溶融還元法の概要}

Fig. 1に2段羽口式溶融還元炉のフローを示す。本プロ セスはコークス充填層の竪型炉の下部に上下 2 段の羽口を 有する炉である3)。上下段の羽口から酸素を富化した熱風 を吹込み各羽口前にレースウェイを形成する。コークスの 燃焼により, 両レースウェイ間には高温かつ高還元性領域
が形成される。粉状の原料はフラックスとともに上段羽口 から吹込まれ, 高温のレースウェイ内で直ちに溶融し, 滴 下しながら還元される。このとき還元熱は下段レースウェ イからの熱で補償され, 高温が維持されるため, 難還元性 の $\mathrm{Cr}_{2} \mathrm{O}_{3}$ などでも還元することができる。生成した溶銑， 溶滓は炉床に滴下し, 出銑孔より排出される。排ガスは コークス充填層を熱交換しながら炉頂へ上昇し, 排ガス清 浄された後, 燃料ガスとして使用される。急冷塔では高温 の排ガスに集塵水を噴射して排ガスを急冷するとともに， 排ガスに含まれるダストを除去する。

\section{3. 実験方法および結果}

\section{$3 \cdot 1$ 実験方法}

$1 \mathrm{t} / \mathrm{d}$ おび $10 \mathrm{t} / \mathrm{d}$ 規模の 2段羽口式溶融還元炉を用いて， スラッジを溶融還元する実験を実施した。1 t/dの炉6)は炉 床径 $0.4 \mathrm{~m}$, コークス充填層の高さ $2.5 \mathrm{~m}$ で, 1 本の上段羽口 と 3 本の下段羽口を持つ。 $10 \mathrm{t} / \mathrm{d}$ の炉 ${ }^{3)}$ は炉床径 $1.2 \mathrm{~m}$ で 1 組 の2段羽口を持つ。

実験に使用したスラッジは，フッ素含有量が低い圧延ス ラッジおよび工場で発生するステンレス酸洗廃液よりハイ ブリッド粗分離法により脱フッ素して得られたスラッジ で, 組成を Table 1に示す。圧延スラッジのフッ素濃度は $0.16 \%$ であるが, これにホタル石を添加してフッ素濃度を 最大 $4 \%$ まで調整した。また, 脱フッ素スラッジにはフッ

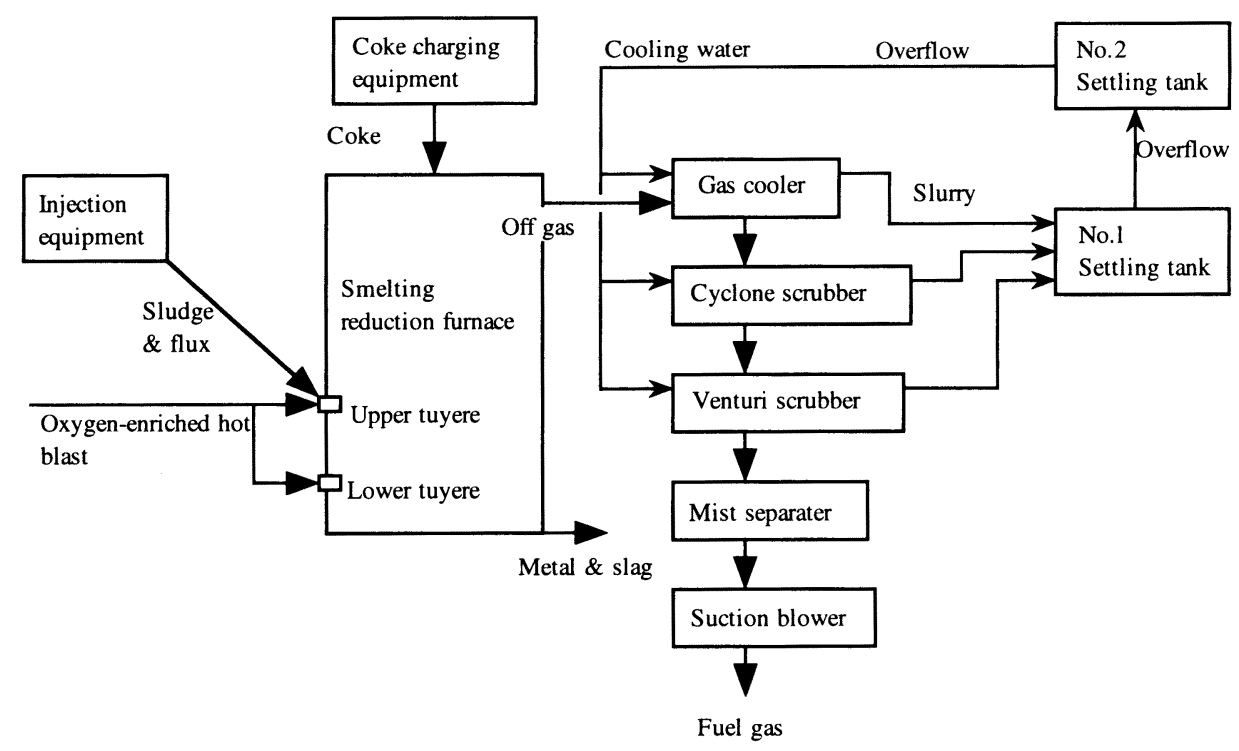

Fig. 1. Process flow of smelting reduction furnace.

Table 1. Chemical composition of sludge.

\begin{tabular}{|l|c|c|c|c|c|c|c|c|}
\hline & T.Fe & T.Cr & $\mathrm{F}$ & $\mathrm{SiO}_{2}$ & $\mathrm{Al}_{2} \mathrm{O}_{3}$ & $\mathrm{CaO}$ & $\mathrm{Na}$ & $\mathrm{CW}$ \\
\hline Strip mill sludge & 43.4 & 4.66 & 0.16 & 3.86 & 2.32 & 6.47 & 0.07 & 8.47 \\
\hline Defluorized sludge & 43.7 & 7.54 & 3.04 & 0.17 & 0.40 & $<0.1$ & 3.73 & 8.76 \\
\hline
\end{tabular}


素が $3.04 \%$ 含まれる。

実験水準は，(1)式に示す有効熱利用率 $R_{q}$, 上段羽口前 の理論燃狫温度 $T_{u}$, 下段羽口の理論燃焼温度 $T_{l}$ をそれぞれ， $0.31 \sim 0.57,1700 \sim 2000^{\circ} \mathrm{C}, 2200 \sim 2700^{\circ} \mathrm{C}$ 範囲で変更した。 このときの操業条件を Table 2 に示す。

$$
R_{q}=Q_{\text {req }} /\left(Q_{\text {in }}-Q_{\text {loss }}\right)
$$

(1)式の $Q_{\text {loss }}$ は熱収支における不明熱とした。ここで $Q_{\text {in }}$ $(\mathrm{kJ})$ は入熱を示し，送風顕熱と $\mathrm{CO}$ までのコークス燃焼熱 の合計, $Q_{\text {loss }}(\mathrm{kJ})$ は炉体放散熱, $Q_{\text {req }}(\mathrm{kJ})$ は還元に必要な 熱で，水酸化物中の結晶水分解熱，金属酸化物の直接還元 熱, 融体顕熱, 水分, 石灰分解熱抢よび結晶水と炭素との 反応熱の合計である。

\section{$3 \cdot 2$ 実験結果}

Fig. 2 に還元挙動を表す各指標 (T.Fe), (T.Cr), [Si], $\left(\mathrm{P}_{2} \mathrm{O}_{5}\right)$ お よび $(\mathrm{MnO}) /[\mathrm{Mn}]$ と $R_{q}$ との関係を $T_{u}$ で層別して示す。また $(\mathrm{MnO}) /[\mathrm{Mn}]$ と $R_{q}$ との関係を示すグラフには酸化物のダス 卜を $10 \mathrm{t} / \mathrm{d}$ おび $200 \mathrm{t} / \mathrm{d}$ の 2 段羽口式溶融還元炉で処理し

Table 2. Operating condition.

\begin{tabular}{|ll|c|c|}
\hline & & $1 \mathrm{t} / \mathrm{d}$ & $10 \mathrm{t} / \mathrm{d}$ \\
\hline Sludge injection rate $\mathrm{kg} / \mathrm{h}$ & $38.2-66.8$ & $138-374$ \\
\hline Blast volume $\quad \mathrm{Nm}^{3} / \mathrm{h}$ & $112-151$ & 1100 \\
\hline Oxygen enrichment $\quad \mathrm{Nm}^{3} / \mathrm{h}$ & $15.0-32.8$ & $71-163$ \\
\hline Coke rate & $\mathrm{kg} / \mathrm{t}-\mathrm{sludge}$ & $1380-1724$ & $1510-3690$ \\
\hline Metal production rate $\mathrm{kg} / \mathrm{h}$ & $17.0-29.3$ & $76-187$ \\
\hline Slag production rate $\mathrm{kg} / \mathrm{h}$ & $13.9-17.0$ & $60-179$ \\
\hline
\end{tabular}

たときのプロットを合わせて示した6)。還元が良好なとき， [Si] を除く各指標は小さな値となり，[Si]は大きな值とな る。各指標は $R_{q}$ と良好な相関が見られる。Fig. 2 に示した ように, 水酸化物であるスラッジに含まれる結晶水の分解 熱打よび炭素との反応熱を考慮することにより，スラッジ 処理時においても $(\mathrm{MnO}) /[\mathrm{Mn}]$ と $R_{q}$ との間に, 従来の酸化 物と同様の関係があることがわかる。 $T_{u}$ の影響に関しては，

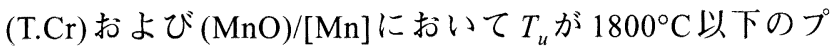
ロットは比較的還元が悪化している側にあるが, 全体とし てははっきりした傾向は見られない。(T.Cr)が他と比較し て著しく低いものが見られるが，[Si]は高めに偏在し，還 元が良好である傾向を示している。これは $T_{l}$ が高いことが 影響していると考えられる。以上のことから，スラッジ処 理時も従来の酸化物と同様に $R_{q}$ を用いた操業設計が妥当 であり， $R_{q}<0.45$ となるように送風条件を調整することに より，良好な還元が得られることが分かった。

Table 1に示したように脱フッ素スラッジのCr濃度は鉄 系スラッジよりも高いので, $[\mathrm{Cr}]$ はべースの約 $6 \sim 7 \%$ から 脱フッ素スラッジ処理時には最高 $9.3 \%$ まで上昇した。し かし，大きな還元性悪化，出銑涬の悪化は見られず，本方 法により問題なく処理できることが分かった。

\section{4. 溶融還元炉におけるフッ素の挙動と分配制 御技術の開発}

\section{$4 \cdot 1$ スラグへのフッ素の分配}

吹込まれたフッ素は，スラグと炉頂から排出される排ガ スおよびダストに分配される。Fig. 3 に $10 \mathrm{t} / \mathrm{d}$ 規模の実験で
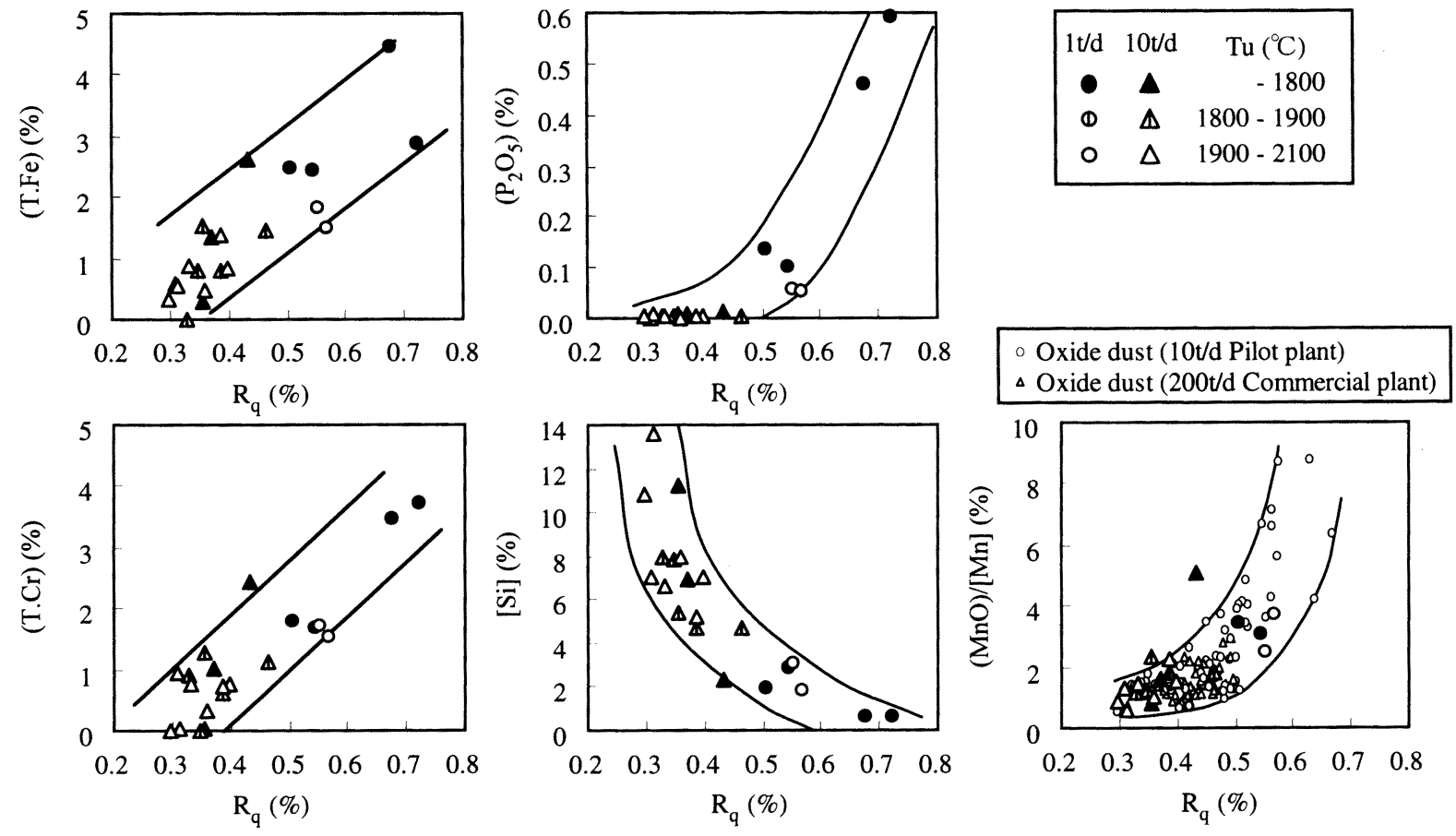

Fig. 2. Effect of operating condition on index of reduction. 


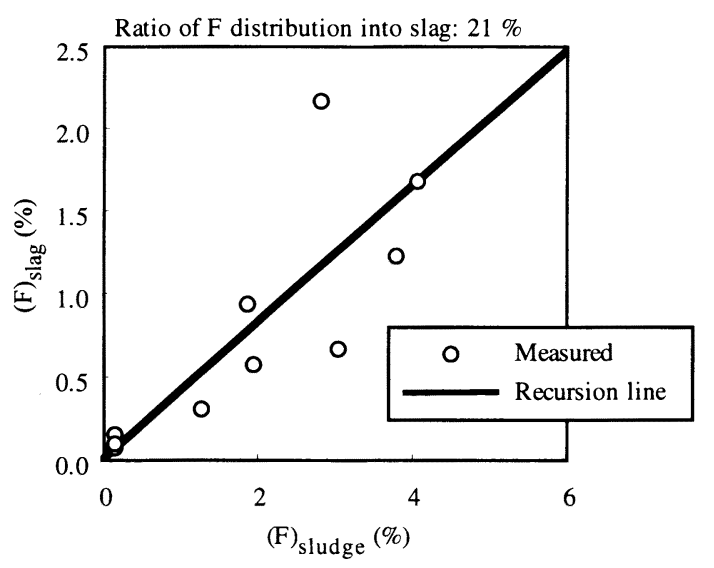

Fig. 3. Relationship between fluorine content in slag and fluorine content in sludge.

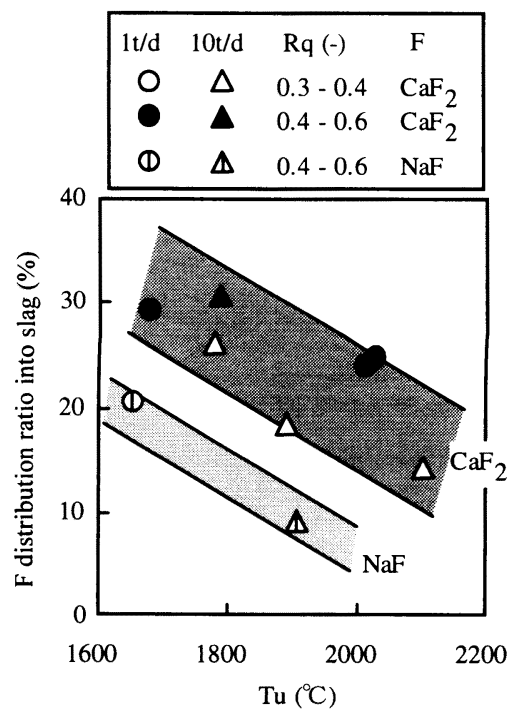

Fig. 4. Effect of $T_{u}$ on fluorine distribution ratio into slag.

得られたスラグ中のフッ素濃度とスラッジ中のフッ素濃度 との関係を示す。スラグ中フッ素濃度は，フッ素吹込み期 間の最終のスラグ濃度とした。スラグへのフッ素分配率は， 図中に示した回帰式の傾き 0.41 と全スラッジ吹込み期間の 平均スラグ比 $511 \mathrm{~kg} / \mathrm{t}$-sludge より, 約 $21 \%$ となった。

Fig. 3のデータにはばらつきが見られ，スラッジ中フッ 素濃度以外の要因により，スラグ中フッ素濃度が影響を受 けていると考えられる。Fig. 4 にスラグへのフッ素分配率 と $T_{u}$ との関係を $R_{q}$ で層別して示す。スラグへのフッ素分 配率は, 第 1 に $T_{u}$, 第 2 に有効熱利用率の影響があること が分かった。すなわち， $T_{u}$ が高く，有効熱利用率が低いと きにスラグへの分配率が低くなった。 $T_{u}$ を $100^{\circ} \mathrm{C}$ 高めるこ とにより，スラグへのフッ素分配率を約 7\%低減すること ができる。 $T_{u}$ が上段羽口前の融体温度を, 有効熱利用率が 上下羽口間の製錬領域の平均的な融体温度を代表すると考 えると, 上段羽口から吹込まれたスラッジ中フッ素は，主 に上段羽口前で溶融するときに蒸発し，さらにスラグと なって上下羽口間を滴下するときにも蒸発がおこることを
Table 3. Calculating condition.

\begin{tabular}{|c|c|c|c|c|}
\hline & & & Case 1 & Case 2 \\
\hline \multirow{10}{*}{$\begin{array}{l}\text { Input } \\
\text { material } \\
\text { (mol) }\end{array}$} & \multirow[t]{4}{*}{ Gas } & $\mathrm{CO}$ & \multicolumn{2}{|c|}{$3.07 \times 10^{1}$} \\
\hline & & $\mathrm{N}_{2}$ & \multicolumn{2}{|c|}{$3.60 \times 10^{1}$} \\
\hline & & $\mathrm{H}_{2}$ & \multicolumn{2}{|c|}{$2.30 \times 10^{1}$} \\
\hline & & $\mathrm{Cl}_{2}$ & \multicolumn{2}{|c|}{$3.00 \times 10^{-2}$} \\
\hline & \multirow[t]{6}{*}{ Solid } & C & \multicolumn{2}{|c|}{$1.00 \times 10^{3}$} \\
\hline & & $\mathrm{SiO}_{2}$ & \multicolumn{2}{|c|}{$4.50 \times 10^{-1}$} \\
\hline & & $\mathrm{CaO}$ & \multicolumn{2}{|c|}{$3.90 \times 10^{-1}$} \\
\hline & & $\mathrm{Al}_{2} \mathrm{O}_{3}$ & \multicolumn{2}{|c|}{$9.00 \times 10^{-2}$} \\
\hline & & $\mathrm{CaF}_{2}$ & $1.50 \times 10^{-1}$ & - \\
\hline & & $\mathrm{NaF}$ & - & $2.90 \times 10^{-1}$ \\
\hline \multicolumn{3}{|c|}{ Pressure } & \multicolumn{2}{|c|}{1.0} \\
\hline
\end{tabular}

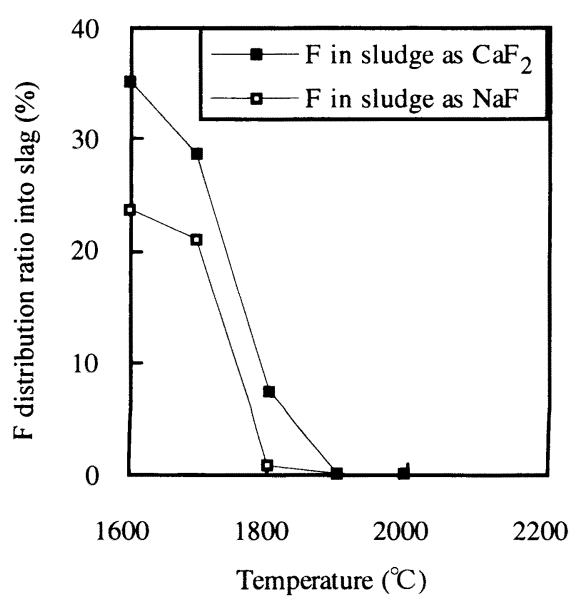

Fig. 5. Equilibrium of fluorine distribution ratio into slag (calculation).

示唆している。

また, Fig. 4にスラッジ中にフッ素が $\mathrm{CaF}_{2}$ の形態で存在 する場合と $\mathrm{NaF}$ の形態で存在する場合との比較を示した。 スラッジ中にフッ素が $\mathrm{NaF}$ の形態で存在する方が, スラグ への分配率が小さいことが分かった。

スラグからのフッ素の蒸発挙動を化学平衡計算ソフト FactSage（ChemSage ${ }^{7}$ と $\mathrm{F}^{*} \mathrm{~A}^{*} \mathrm{C}^{*} \mathrm{~T}^{8)}$ を結合したソフト）を 用いて計算した。計算には理想気体としてのガス相, Cお よび $\mathrm{CaO}-\mathrm{SiO}_{2}-\mathrm{Al}_{2} \mathrm{O}_{3}$ に該当する化合物，スラグ相を $\mathrm{F}^{*} \mathrm{~A}{ }^{*} \mathrm{C} * \mathrm{~T}$ データベースから引用して用いた。なお Cはグ ラファイトとして取り扱った。前述のように，実験におい て圧延スラッジにはホタル石 $\left(\mathrm{CaF}_{2}\right)$ を添加し, 脱フッ素ス ラッジにはNaFが含まれるので，Table 3に示すように， $\mathrm{CaF}_{2}$ および $\mathrm{NaF}$ をッ素源とする2ケースで計算を行っ た。

Fig. 5にスラグへのフッ素分配率と温度の関係の計算結 果を示す。計算結果はいずれの場合も温度が高くなるほど スラグへのフッ素分配率が低下した。また $\mathrm{NaF}$ 方がスラ グへのフッ素分配率が低くなった。これらの傾向は定性的 に実験結果と一致した。Fig. 4 と比較して実験結果の方が 計算結果よりもスラグへのフッ素分配率が高いのは，実際 

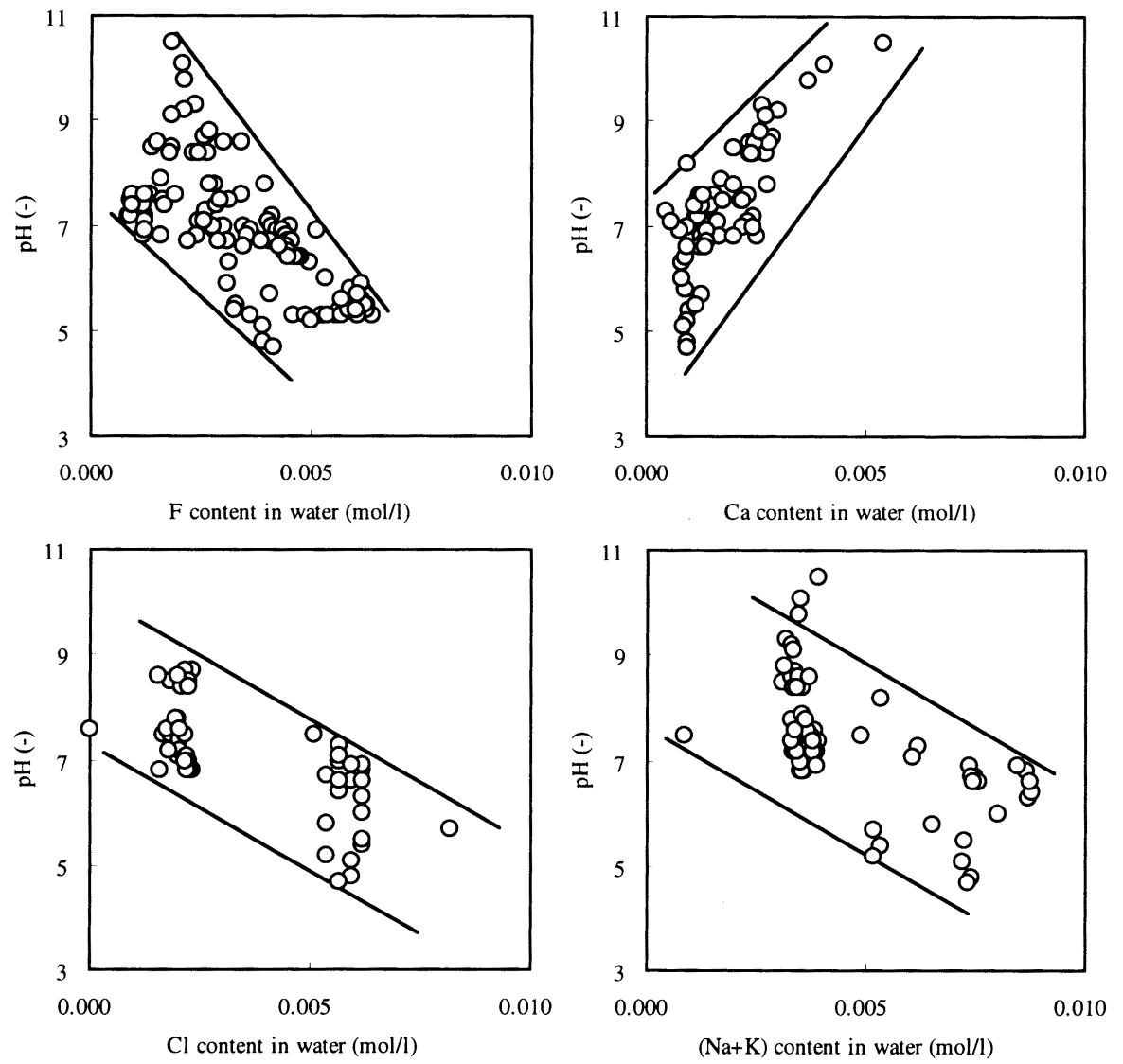

Fig. 6. Relationship between $\mathrm{pH}$ and ion concentration in cooling water.

の融体の温度が $T_{u}$ よりも低いためと考えられる。また， 前述のようにフッ素の蒸発が上下羽口間の滴下中にもおこ ると考えられるので，製錬領域の平均的な融体温度の影響 も考慮する必要があると考えられる。

なお，平衡計算から得られた主な高蒸気圧のフッ素含有 化学種は, $1600^{\circ} \mathrm{C}$ 以上では $\mathrm{AlF}, \mathrm{CaF}, \mathrm{CaF}_{2}, \mathrm{HF}$ などであり, $1600^{\circ} \mathrm{C}$ 以下では, $\mathrm{HF}, \mathrm{SiF}_{4}$ などで, $\mathrm{NaF}$ 添加した場合は これに NaFが加わる。フッ素はこれらの形態で気相に移行 しているものと考えられる。

以上のことから，スラッジ中のフッ素は羽口から吹込ま れると加熱され，一部が $\mathrm{AlF}, \mathrm{CaF}, \mathrm{CaF}_{2}, \mathrm{HF}, \mathrm{SiF}_{4}$ および $\mathrm{NaF}$ の形で蒸発し，排ガスとともに炉頂から排出され，残りが スラグ中へ分配されると考えられる。 $R_{q}$ が低いまたは羽口 前温度が高いときはフッ素の蒸発量が増加し，スラグへの 分配率が低下する。また，フッ素含有スラッジは上段羽口 より吹込まれるため, $T_{u}$ との相関が強いことが分かった。

\section{$4 \cdot 2$ 集塵水へのフッ素の分配}

本実験において集塵水は循環使用されている。Fig. 1に 示したように，排ガスは急冷塔，サイクロンスクラバーお よびべンチュリースクラバーを通過する際に，第2沈殿槽 の上澄み液の散水により除塵される。このとき排ガス中 $\mathrm{HF}$ が水中に溶解する。集塵水はいったん各除塵装置下部 の水槽に溜まり，スラリ一状で第 1 沈殿槽に移送される。
第 1 沈殿槽で固体粒子（ダスト）は沈降分離され，上澄み 液は第2 沈殿槽へオーバーフローし，循環使用される。第 1 沈殿槽下部に沈殿したダストはスラリー状で下部から抜 き出され，脱水され，液体のみ第2 沈殿槽に戻される。

実験終了後, 集塵水中のフッ素分析值とその量から集塵 水へのフッ素分配量を求め, 全実験期間中に原料として吹 込まれたインプットフッ素量との比から，実験期間全体を 通しての集塵水へのフッ素分配率を求めると $8 \%$ と計算さ れた。前述のスラグへの分配率 $21 \%$ を除く残余の $70 \%$ は， 排ガスおよび除塵されたダストに分配されたと考えられ る。

集塵水の $\mathrm{pH}$ を低下させる要因は, 羽口から吹込まれた 原料中の $\mathrm{Cl}, \mathrm{F}$ が $\mathrm{HCl}, \mathrm{HF}$ となり，集塵水に溶解して $\mathrm{pH}$ 低下させることが考えられる。反対に $\mathrm{pH}$ を昇させる要 因は，スラグ成分調整のために吹込まれた $\mathrm{CaCO}_{3}$ が熱分解 して $\mathrm{CaO}$ となり，一部はダストとして排ガスとともに排 出され，集塵水中で $\mathrm{Ca}(\mathrm{OH})_{2}$ となり, $\mathrm{pH}$ 昇させるこ とと，スラッジ中に含まれる $\mathrm{Na}_{2} \mathrm{O}, \mathrm{K}_{2} \mathrm{O}$ が, $\mathrm{NaOH}, \mathrm{KOH}$ と して $\mathrm{pH}$ を昇させることがあると考えられる。集塵水の $\mathrm{pH}$ はこれらの量のバランスで決定されると考えられる。

Fig. 6 に $10 \mathrm{t} / \mathrm{d}$ 規模の実験時の, 集塵水 $\mathrm{pH}$ と集塵水中の 濃度の高かった $\mathrm{F}, \mathrm{Cl}, \mathrm{Ca}$ および $(\mathrm{Na}+\mathrm{K})$ 濃度との関係を示 す。集塵水 $\mathrm{pH}$ はこれらと比較的高い相関が見られる。 
溶液中では電気的中性が成り立つのでイオンとして $\mathrm{H}^{+}$, $\mathrm{Na}^{+}, \mathrm{K}^{+}, \mathrm{Ca}^{2+}, \mathrm{OH}^{-}, \mathrm{Cl}^{-}, \mathrm{F}^{-}$が存在すると仮定すると(2)式 が成り立つ。[ ]は各イオンのモル濃度 $(\mathrm{mol} / \mathrm{l})$ を示す。

$\left[\mathrm{H}^{+}\right]+\left[\mathrm{Na}^{+}\right]+\left[\mathrm{K}^{+}\right]+2\left[\mathrm{Ca}^{2+}\right]=\left[\mathrm{OH}^{-}\right]+\left[\mathrm{Cl}^{-}\right]+\left[\mathrm{F}^{-}\right] \cdots \cdots(2)$

変形して,

$\left[\mathrm{H}^{+}\right]-\left[\mathrm{OH}^{-}\right]=\left(\left[\mathrm{Cl}^{-}\right]+\left[\mathrm{F}^{-}\right]\right)-\left(2\left[\mathrm{Ca}^{2+}\right]+\left[\mathrm{Na}^{+}\right]+\left[\mathrm{K}^{+}\right]\right) \cdots($

各元素が水中で完全に解離していると仮定して，(3)式の 右辺のイオン濃度に集塵水の分析值を用い, これと $\mathrm{pH}$ と の関係を Fig. 7 に示す。困には $\left[\mathrm{H}^{+}\right]\left[\mathrm{OH}^{-}\right]=1 \times 10^{-14}$ とした ときの理論中和曲線も合わせ示した。プロットは，横軸が 0のとき $\mathrm{pH}$ が約 7 となり，おおむね(3)式が成立している と考えられる。また，横軸の数值が大きくなる，すなわち 相対的に $\mathrm{HCl}$ や $\mathrm{HF}$ が多く溶解すると $\mathrm{pH}$ が低下することを 示している。どのようなイオンが働いているか特定はでき なかったが, 理論中和曲線と実験結果が完全に一致しない のは，洗浄液の緩衝作用によるものと考えられる。

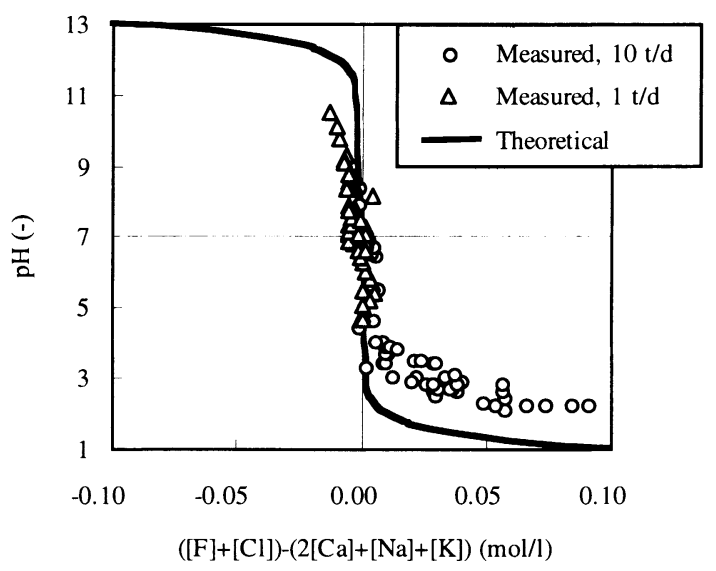

Fig. 7. Relationship between $\mathrm{pH}$ and $([\mathrm{F}]+[\mathrm{Cl}])-(2[\mathrm{Ca}]+$ $[\mathrm{Na}]+[\mathrm{K}]$ ) in cooling water.

\section{5. スラグ中フッ素の溶出挙動}

Fig. 8 にスラグからのフッ素溶出量とスラグ中フッ素濃 度との関係を示す。フッ素濃度が上昇すると溶出が増加す る関係が見られる。しかしながら，本実験の範囲ではいず れの測定值も規制值 $0.8 \mathrm{mg} / l$ 以下であった。

スラッジ中フッ素濃度上限の考え方を Fig. 9 に示す。ス ラグ中フッ素濃度はスラッジ中フッ素濃度, 操業条件に よって決まるスラグへのフッ素分配率およびスラグ比に よって決まる。一方, 集塵水 $\mathrm{pH}$ は酸性成分である $\mathrm{HCl}, \mathrm{HF}$ の飛散量とアルカリ成分である $\mathrm{CaO}, \mathrm{Na}_{2} \mathrm{O}, \mathrm{K}_{2} \mathrm{O}$ の飛散量の バランスで決まると考えられる。また $\mathrm{HCl}, \mathrm{HF}, \mathrm{Na}_{2} \mathrm{O}, \mathrm{K}_{2} \mathrm{O}$ の飛散量は, スラッジ, 塩基度調整剂, コークスなど, 原 料中のこれらの濃度に影響される。一方 $\mathrm{CaO}$ は塩基度調 整剤中に豊富にあり，ほとんどがスラグとなるので，炉頂 ガス流速やコークス粒径などの条件による影響が大きいと 考えられる。

今回の実験条件である, スラッジ中のフッ素濃度 $4 \%$, ス ラグへの分配率 $21 \%$ ，スラグ比 $511 \mathrm{~kg} / \mathrm{t}$-sludge の場合，スラ

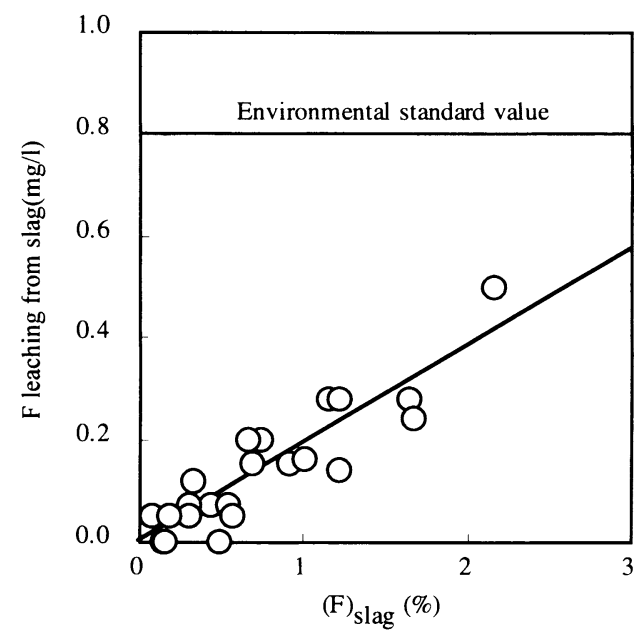

Fig. 8. Result of fluorine leaching test.

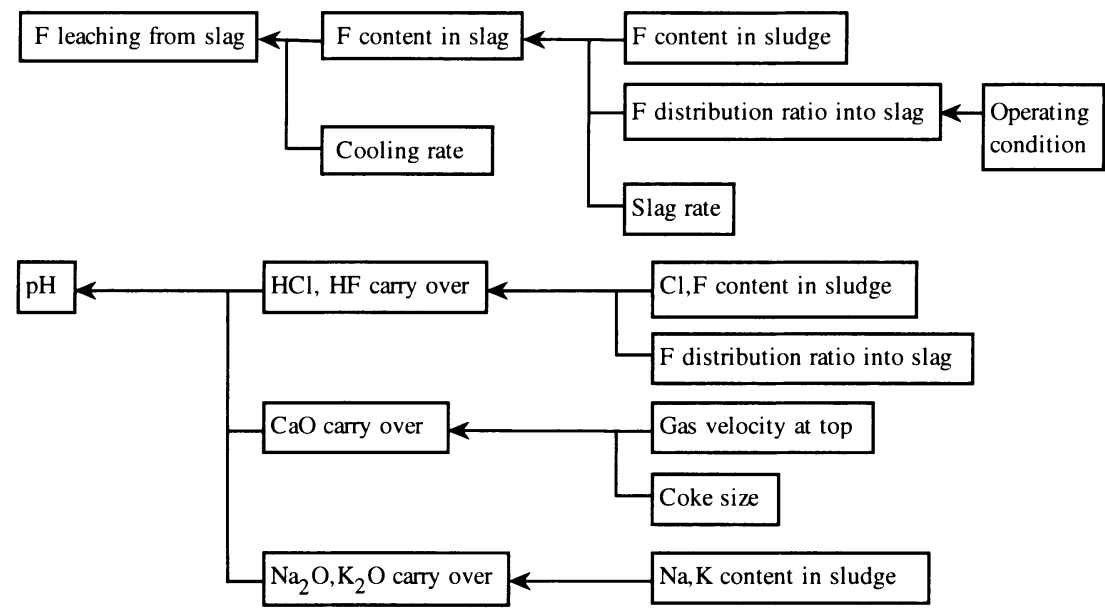

Fig. 9. Determination flow of maximum fluorine content in sludge. 
グ中フッ素濃度は $1.64 \%$, スラグからのフッ素溶出は 0.32 $\mathrm{mg} /$ ととなり, 規制值の $0.8 \mathrm{mg} /$ よりりも下回る。スラッジ中 のフッ素濃度が高くなった場合には, Fig. 4に示したよう に $T_{u}$ や $R_{q}$ を高くすることによって，スラグへのフッ素分 配率を低減することが可能である。Fig. 9の考え方に基づ き，スラッジ中フッ素濃度，操業条件を決定すれば，スラ グからのフッ素の溶出を低減することができると考えられ る。

\section{6. 結言}

ハイブリッド粗分離法により脱フッ素したスラッジを， 2段羽口式溶融還元炉を用いて処理する技術を開発した。

（1）必要熱として水酸化物中の結晶水分解熱と結晶水 と炭素との反応熱を考慮することにより, 有効熱利用率と 還元挙動との関係において, 水酸化物の還元挙動は酸化物 のそれと同等と評価でき, 有効熱利用率を 0.45 以下で操業 を行えば，良好な還元が得られることが分かった。

（2）2段羽口式溶融還元炉内のフッ素の挙動を明らか にし, 炉熱打よび上段羽口の理論燃焼温度により, フッ素
のスラグへの分配率を制御する技術を開発した。 $T_{u}$ を $100^{\circ} \mathrm{C}$ 高めることにより，スラグへのフッ素分配率を約 7\%低減することができることが分かった。

(3) 集塵水 $\mathrm{pH}$ 低下は酸性成分とアルカリ成分の飛散 量のバランスで決まることを明らかにした。

本研究の一部は, 地球環境産業技術研究機構の地球環境 保全関係産業技術開発促進事業として補助を受けて実施し た。ここに謝意を表す。

\section{文献}

1 ）金属系二次資源有効活用部会調査報告書, 金属系材料研究開 発センター編，東京，(1996), 277.

2 ) H.Uesugi, Y.Hara, F.Tanno, T.Nakamura and E.Shibata: Tetsu-toHagané, 88 (2002), 580.

3 ) Y.Hara, N.Ishiwata, H.Itaya and T.Matsumoto: ISIJ Int., 40 (2000), 231.

4 ) O.Kubaschewski, E.L.L.Evans and C.B.Alcock: Metallurgical Thermochemistry, Pergamon, Oxford, (1974), 322.

5 ) 化学便覧基礎編改訂 4版, 日本化学会編, 丸善, 東京, (1993), II-285.

6 ) S.Hasegawa, H.Kokubu and Y.Hara: Kawasaki Steel Tech. Rep., 38 (1998), 32.

7 ) G.Eriksson and K.Hack: Metall. Trans. B, 21B (1990), 1013

8 ) A.D.Pelton: High Temp. Sci., 26 (1988-1989), 231. 